\title{
Water-Quality and Geochemical Variability in the Little Arkansas River and Equus Beds Aquifer, South-Central Kansas, 2001-16
}

\section{Abstract}

This fact sheet describes water quality and geochemistry of the Little Arkansas River and Equus Beds aquifer during 2001 through 2016 as part of the City of Wichita's Equus Beds aquifer storage and recovery project in south-central Kansas. The Equus Beds aquifer storage and recovery project was developed to help meet future water demand by pumping water out of the Little Arkansas River (during above-base-flow conditions), treating it using National Primary Drinking Water Regulations as a guideline, and injecting it into the aquifer for later use. Waterquality data were collected and analyzed by the U.S. Geological Survey from 2 Little Arkansas River surface-water sites and 63 Equus Beds groundwater sites, including 38 areal assessment index wells, each of which has a shallow well and a deep well. About 4,700 surface and groundwater samples were collected and analyzed for more than 300 water-quality constituents. About 1,300 groundwater chemistry samples were geochemically modeled. Constituents of concern in the Equus Beds aquifer exceeded their respective Federal criteria throughout the study period and included chloride, sulfate, nitrate plus nitrite, Escherichia coli (E. coli), total coliforms, and dissolved iron and arsenic species.

\section{Introduction}

The Equus Beds aquifer is a primary water source for the city of Wichita, Kansas (fig. 1). Historically, the volume of water that has been pumped out of parts of the aquifer has exceeded its natural recharge rate; thus, aquifer water levels have decreased substantially (Klager, 2016; Whisnant and others, 2015; Hansen and others, 2014). The easternmost area of the aquifer, including the Wichita well field, is susceptible to saltwater contamination from the Arkansas River (fig. 1) and saltwater intrusion from existing upgradient contamination plumes caused by 1930s oil field evaporation pits (Whittemore, 2007; Klager and others, 2014). The Equus Beds aquifer storage and recovery project was created to help the city meet increasing future water demands, and, as an added benefit, the aquifer storage and recovery project can also inhibit saltwater encroachment into the uncontaminated parts of the aquifer (Ziegler and others, 2010; Klager and others, 2014). Source water for artificial recharge is obtained from the Little Arkansas River during above-base-flow conditions, is treated using National Primary Drinking Water Regulations as a guideline, and is injected into the Equus Beds aquifer through recharge wells and spreading basins for later use.

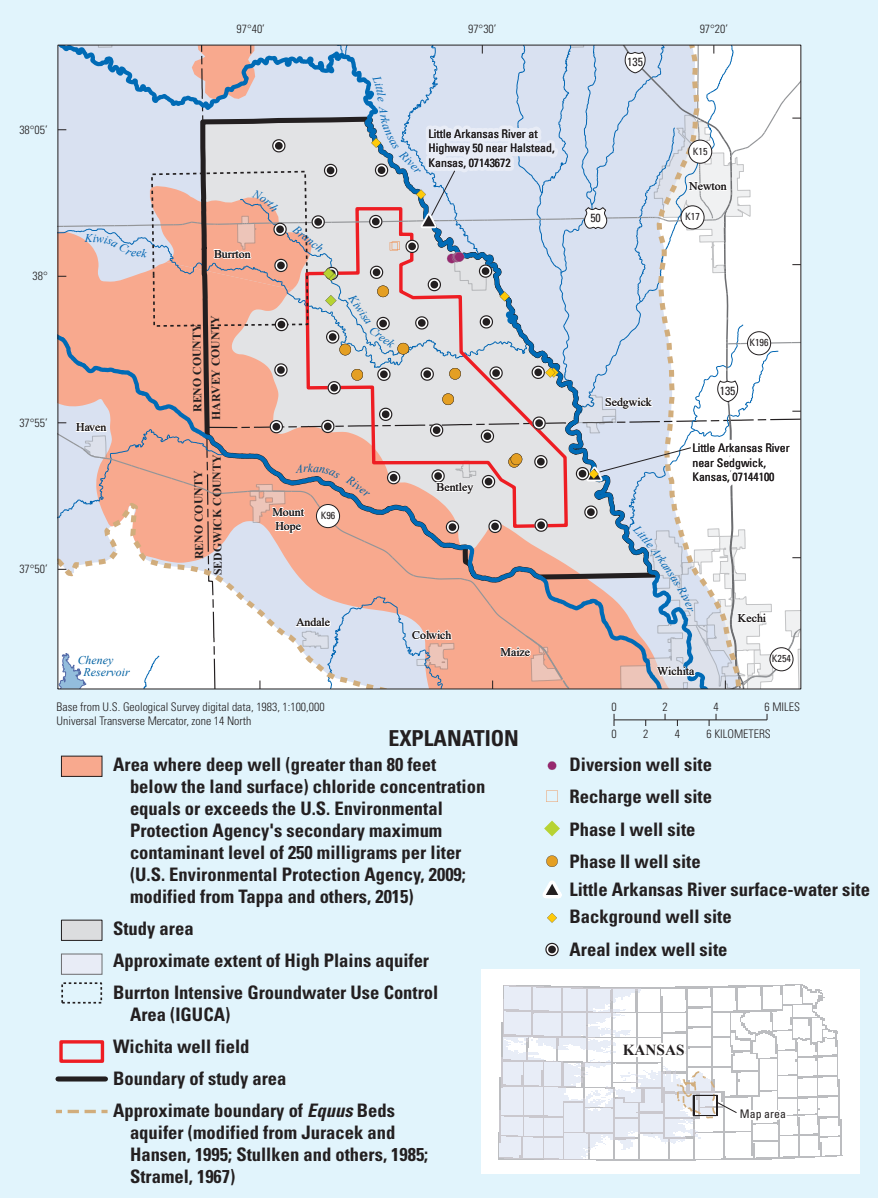

Figure 1. Location of study area near Wichita, south-central Kansas (modified from Hansen and others, 2014; Tappa and others, 2015; and Whisnant and others, 2015).

The purpose of this fact sheet is to summarize and highlight water-quality and geochemical variability findings in the Little Arkansas River and the Equus Beds aquifer during 2001 through 2016 in the jointly released U.S. Geological Survey Scientific Investigations Report of the same title. The data summarized in this fact sheet and described in detail in the companion Scientific Investigations Report will be used to establish baseline conditions before further implementation of artificial aquifer recharge, document surface and groundwater quality, evaluate changing conditions, identify environmental factors affecting surface and groundwater, provide science-based information for decision making, and help meet regulatory requirements. Refer to Stone and others (2019) for more details about information presented in this fact sheet. 


\section{Water Quality of the Little Arkansas River and Equus Beds Aquifer}

Surface-water and groundwater physicochemical properties and water-quality constituents that frequently exceeded EPA Federal drinking water-quality criteria and those that are of potential interest or concern for artificial recharge operations include chloride, sulfate, nitrate plus nitrite, iron, manganese, arsenic, and atrazine. Equus Beds aquifer index well (IW) geochemical equilibria characterize groundwater geochemistry.

\section{Chloride}

Chloride is a major constituent of concern because of its persistence in groundwater from a chloride plume near Burrton, Kans., from past oil and gas activities and because of highly variable concentrations in the Little Arkansas River that can exceed drinking-water standards (Tappa and others, 2015). The U.S. Environmental Protection Agency (EPA) secondary maximum contaminant level (SMCL) for chloride is 250 milligrams per liter (mg/L; U.S. Environmental Protection Agency, 2009) for aesthetics, including taste and odor. Chloride exceeded the EPA SMCL in less than $(<) 1$ percent of samples from the two Little Arkansas River surface-water sites and ranged from $<5$ to $530 \mathrm{mg} / \mathrm{L}$ (table 1). Shallow index well (IW) chloride ranged from $<5$ to $773 \mathrm{mg} / \mathrm{L}$, and deep IW chloride ranged from $<5$ to $1,460 \mathrm{mg} / \mathrm{L}$ (table 1). About 5 percent of shallow and 7 percent of deep IW chloride sample concentrations exceeded the SMCL during 2001 through 2016 (table 1). Wells along the Arkansas River and near Burrton, Kans., had mean chloride concentrations that exceeded the SMCL (fig. 2). Chloride concentrations generally were larger in deep wells likely because of several mechanisms: saltwater migration downward from 1930s era brine disposal pits, natural upward movement of saltwater through natural fractures in underlying bedrock or wells, and infiltration of less dense freshwater by rainfall (Whittemore, 2007; Leonard and Kleinschmidt, 1976).

\section{Sulfate}

The EPA SMCL for sulfate is $250 \mathrm{mg} / \mathrm{L}$ (U.S. Environmental Protection Agency, 2009). Surface-water sulfate concentrations did not exceed the SMCL at the surface-water sites in this study (table 1). Shallow IW sulfate ranged from $<5$ to $770 \mathrm{mg} / \mathrm{L}$ (mean of $152 \mathrm{mg} / \mathrm{L}$ ), and deep IW sulfate ranged from $<5$ to $720 \mathrm{mg} / \mathrm{L}$ (mean of $111 \mathrm{mg} / \mathrm{L}$; table 1 ). About 18 percent of shallow and 13 percent of deep IW sulfate concentrations exceeded the SMCL during 2001 through 2016 (table 1). Mean sulfate concentrations that exceeded the SMCL were mostly in the central part of the study area. These areas of larger sulfate concentrations are where the aquifer is the thickest and generally are associated with areas that were substantially dewatered through 1993 and have subsequently recovered (Ziegler and others, 2010; Tappa and others, 2015).

\section{Nitrate}

Nitrate is the nutrient of most concern for the Equus Beds aquifer and often exceeds the EPA maximum contaminant level (MCL) of $10 \mathrm{mg} / \mathrm{L}$ (U.S. Environmental Protection Agency, 2009; Ziegler and others, 2010; Tappa and others, 2015; Stone and others, 2016). Surface-water nitrate plus nitrite (hereafter

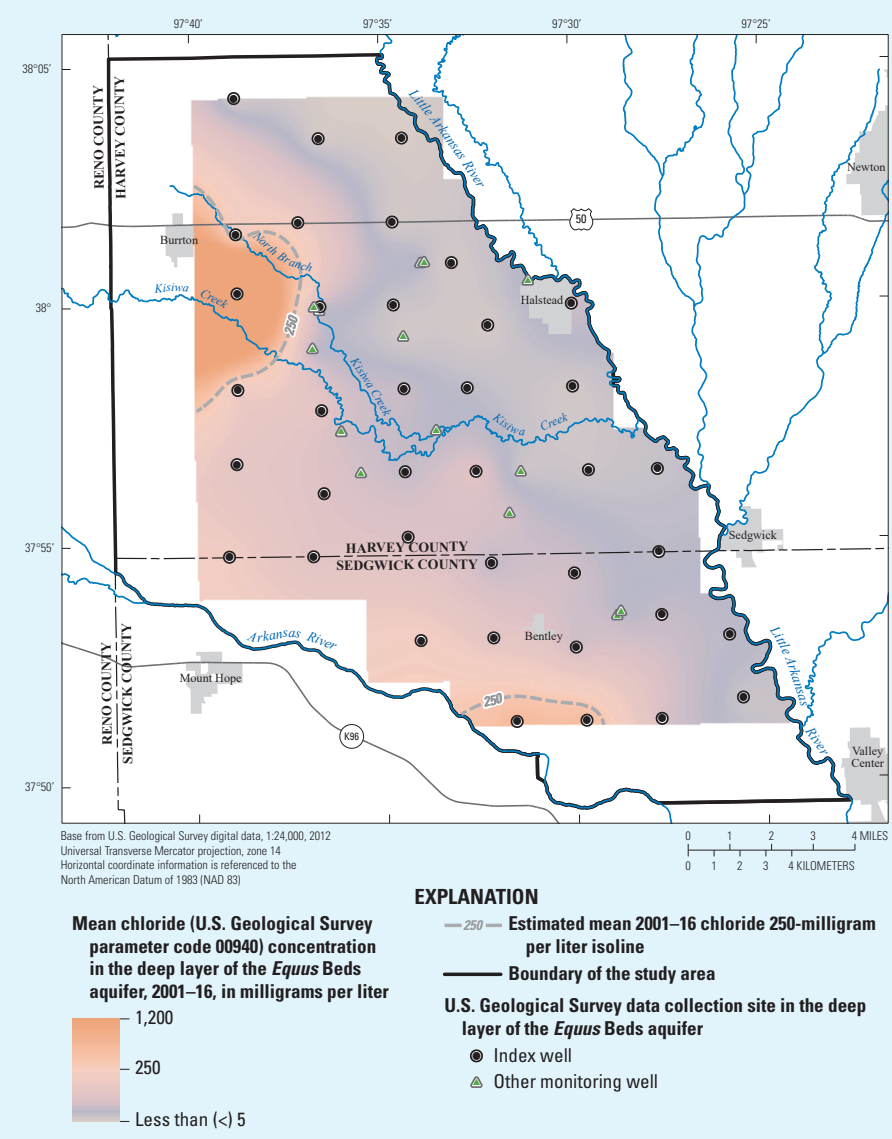

Figure 2. Mean chloride concentrations in the deep parts (depths below land surface greater than 80 feet) of the Equus Beds aquifer, 2001-16.

referred to as "nitrate" for consistency with previous studies) concentrations exceeded the MCL in $<1$ percent of samples (table 1). Mean shallow IW nitrate was about 690 percent larger than mean deep IW nitrate (table 1). About 15 percent of shallow and $<1$ percent of deep IW nitrate concentrations exceeded the MCL during 2001 through 2016 (table 1). Mean shallow IW nitrate concentrations that exceeded the MCL were in the northeastern and southeastern parts of the study area (fig. 3). Larger mean nitrate concentrations that were in the southeastern part of the study area are in the area having larger effective porosity (Ziegler and others, 2010; Tappa and others, 2015) and were likely the result of more rapid percolation from agricultural land uses and geochemical controls. Nitrate from fertilizer runoff, feedlots, and sewage lagoons is more likely to increase concentrations in the shallow parts of the aquifer. Smaller nitrate concentrations at larger depths to water levels of the aquifer may be a result of more reducing conditions (smaller oxidation-reduction potential [ORP] values; figs. $3 ; 4 A, B)$.

\section{Iron}

The SMCL for iron is 300 micrograms per liter $(\mu \mathrm{g} / \mathrm{L}$; U.S. Environmental Protection Agency, 2009), and it is commonly exceeded in the Equus Beds aquifer (Ziegler and others, 2010; Tappa and others, 2015; Stone and others, 2016). Surfacewater dissolved iron concentrations exceeded the SMCL in 7 percent of samples (table 1). Dissolved iron concentrations exceeded the SMCL in 38 percent of shallow IWs and 46 percent of deep IWs (table 1). The largest dissolved iron concentrations 
Table 1. Little Arkansas River surface-water and Equus Beds areal assessment index well groundwater water-quality constituents and mineral saturation indices summary statistics, 2001-16.

[MCL, U.S. Environmental Protection Agency maximum contaminant level; SMCL, U.S. Environmental Protection Agency secondary maximum contaminant level; MCLG, U.S. Environmental Protection Agency maximum contaminant level goal; USGS, U.S. Geological Survey; pcode, parameter code; $n$, number of samples; min, minimum; max, maximum; mg/L, milligram per liter; <, less than; cfu/100 mL, colony forming units per 100 milliliters; $\mu \mathrm{g} / \mathrm{L}$, microgram per liter; SI, saturation index; --, not applicable]

\begin{tabular}{|c|c|c|c|c|c|c|c|c|}
\hline $\begin{array}{c}\text { Water-quality constituent or mineral } \\
\text { phase }\end{array}$ & $\begin{array}{l}\text { Federal MCL or } \\
\text { SMCL or MCLG }\end{array}$ & $\begin{array}{l}\text { USGS } \\
\text { pcode }\end{array}$ & $n$ & Min & Max & Mean & Median & $\begin{array}{l}\text { Percent exceeding } \\
\text { MCL or SMCL }\end{array}$ \\
\hline \multicolumn{9}{|c|}{ Surface water } \\
\hline Chloride, in $\mathrm{mg} / \mathrm{L}$ & $250 \mathrm{mg} / \mathrm{L}$ & 00940 & 387 & $<5$ & 530 & 84.3 & 60.0 & $<1$ \\
\hline Sulfate, in $\mathrm{mg} / \mathrm{L}$ & $250 \mathrm{mg} / \mathrm{L}$ & 00945 & 387 & $<5$ & 170 & 39 & 38 & 0 \\
\hline Nitrate plus nitrite as nitrogen, in $\mathrm{mg} / \mathrm{L}$ & $10 \mathrm{mg} / \mathrm{L}$ & 00631 & 389 & $<0.02$ & 11.7 & 1.11 & 0.85 & $<1$ \\
\hline Total coliform bacteria, in cfu/ $100 \mathrm{~mL}$ & $0 \mathrm{cfu} / 100 \mathrm{~mL}$ & 31504 & 181 & 30 & 360,000 & 14,351 & 2,440 & 100 \\
\hline Iron, in $\mu \mathrm{g} / \mathrm{L}$ & $300 \mu \mathrm{g} / \mathrm{L}$ & 01046 & 370 & $<4$ & 620 & 81 & 50 & 7 \\
\hline Manganese, in $\mu \mathrm{g} / \mathrm{L}$ & $50 \mu \mathrm{g} / \mathrm{L}$ & 01056 & 291 & $<1$ & 826 & 129 & 42 & 48 \\
\hline Arsenic, in $\mu \mathrm{g} / \mathrm{L}$ & $10 \mu \mathrm{g} / \mathrm{L}$ & 01000 & 376 & $<1$ & 16.2 & 5.77 & 5.00 & 12 \\
\hline Atrazine, in $\mu \mathrm{g} / \mathrm{L}$ & $3.0 \mu \mathrm{g} / \mathrm{L}$ & 39632 & 358 & $<0.025$ & 48.0 & 4.73 & 1.61 & 39 \\
\hline \multicolumn{9}{|c|}{ Shallow index wells } \\
\hline Chloride, in $\mathrm{mg} / \mathrm{L}$ & $250 \mathrm{mg} / \mathrm{L}$ & 00940 & 705 & $<5$ & 773 & 67.0 & 36 & 5 \\
\hline Sulfate, in $\mathrm{mg} / \mathrm{L}$ & $250 \mathrm{mg} / \mathrm{L}$ & 00945 & 699 & $<5$ & 770 & 152 & 100 & 18 \\
\hline Nitrate plus nitrite as nitrogen, in $\mathrm{mg} / \mathrm{L}$ & $10 \mathrm{mg} / \mathrm{L}$ & 00631 & 705 & $<0.02$ & 42.6 & 3.79 & 0.70 & 15 \\
\hline Total coliform bacteria, in $\mathrm{cfu} / 100 \mathrm{~mL}$ & $0 \mathrm{cfu} / 100 \mathrm{~mL}$ & 31504 & 441 & $<1$ & 368 & 7 & 1 & 3 \\
\hline Iron, in $\mu \mathrm{g} / \mathrm{L}$ & $300 \mu \mathrm{g} / \mathrm{L}$ & 01046 & 695 & $<5$ & 40,700 & 2,437 & 107 & 38 \\
\hline Manganese, in $\mu \mathrm{g} / \mathrm{L}$ & $50 \mu \mathrm{g} / \mathrm{L}$ & 01056 & 692 & $<1$ & 1,660 & 279 & 90 & 55 \\
\hline Arsenic, in $\mu \mathrm{g} / \mathrm{L}$ & $10 \mu \mathrm{g} / \mathrm{L}$ & 01000 & 703 & $<1.0$ & 55.0 & 3.83 & 1.50 & 12 \\
\hline Atrazine, in $\mu \mathrm{g} / \mathrm{L}$ & $3.0 \mu \mathrm{g} / \mathrm{L}$ & 39632 & 246 & $<0.006$ & 2.280 & 0.062 & 0.009 & 0 \\
\hline Calcite, SI & -- & -- & 679 & -3.60 & 0.27 & -0.71 & -0.51 & -- \\
\hline Iron (III) hydroxide, SI & -- & -- & 679 & -4.75 & 4.34 & 0.72 & 0.60 & -- \\
\hline Iron hydroxide, SI & -- & -- & 679 & -13.69 & 6.88 & -2.52 & -1.92 & -- \\
\hline \multicolumn{9}{|c|}{ Deep index wells } \\
\hline Chloride, in $\mathrm{mg} / \mathrm{L}$ & $250 \mathrm{mg} / \mathrm{L}$ & 00940 & 708 & $<5$ & 1,460 & 110.0 & 65 & 7 \\
\hline Sulfate, in $\mathrm{mg} / \mathrm{L}$ & $250 \mathrm{mg} / \mathrm{L}$ & 00945 & 705 & $<5$ & 720 & 111 & 69 & 13 \\
\hline Nitrate plus nitrite as nitrogen, in $\mathrm{mg} / \mathrm{L}$ & $10 \mathrm{mg} / \mathrm{L}$ & 00631 & 713 & $<0.02$ & 11.3 & 0.48 & 0.01 & $<1$ \\
\hline Total coliform bacteria, in cfu/ $100 \mathrm{~mL}$ & $0 \mathrm{cfu} / 100 \mathrm{~mL}$ & 31504 & 442 & $<1$ & 84 & -- & -- & 3 \\
\hline Iron, in $\mu \mathrm{g} / \mathrm{L}$ & $300 \mu \mathrm{g} / \mathrm{L}$ & 01046 & 702 & $<5$ & 17,900 & 1,441 & 150 & 46 \\
\hline Manganese, in $\mu \mathrm{g} / \mathrm{L}$ & $50 \mu \mathrm{g} / \mathrm{L}$ & 01056 & 707 & $<1$ & 1,640 & 440 & 310 & 92 \\
\hline Arsenic, in $\mu \mathrm{g} / \mathrm{L}$ & $10 \mu \mathrm{g} / \mathrm{L}$ & 01000 & 705 & $<1.0$ & 23.9 & 7.43 & 6.00 & 34 \\
\hline Atrazine, in $\mu \mathrm{g} / \mathrm{L}$ & $3.0 \mu \mathrm{g} / \mathrm{L}$ & 39632 & 183 & $<0.007$ & 0.090 & 0.009 & 0.004 & 0 \\
\hline Calcite, SI & -- & -- & 655 & -1.33 & 0.84 & -0.21 & -0.16 & -- \\
\hline Iron (III) hydroxide, SI & -- & -- & 655 & -4.69 & 4.63 & 0.71 & 0.63 & -- \\
\hline Iron hydroxide, SI & -- & -- & 655 & -13.49 & 7.89 & -1.35 & -0.90 & -- \\
\hline
\end{tabular}

were detected mostly in the central and northwest parts of the study area. Equus Beds aquifer dissolved iron most likely occurs naturally from pyrite $\left(\mathrm{FeS}_{2}\right)$ oxidation in aquifer clay. Substantially large (greater than $3,000 \mu \mathrm{g} / \mathrm{L}$ ) iron concentrations in the shallow parts of the aquifer are associated with areas of larger historical water-level declines and subsequent recovery (Tappa and others, 2015). Ferric oxyhydroxides formed from oxidation of the aquifer material during previous dewatering are likely chemically reduced as groundwater levels recover, thereby increasing dissolved iron concentrations after an increase in water levels (Tappa and others, 2015).

\section{Arsenic}

The MCL for arsenic is $10 \mu \mathrm{g} / \mathrm{L}$ (U.S. Environmental Protection Agency, 2009), and arsenic concentrations frequently exceeded the MCL in groundwater in the study area. Little
Arkansas River surface-water arsenic concentrations exceeded the MCL in about 12 percent of samples (table 1). About 12 percent of shallow IW dissolved arsenic concentrations and 34 percent of deep IW dissolved arsenic concentrations exceeded the MCL (table 1). Shallow IW dissolved arsenic concentrations were larger near the Little Arkansas River and the center of the study area (fig. 5).

Shallow IW dissolved arsenic concentrations are not substantially related to $\mathrm{pH}$ in the Equus Beds aquifer (Ziegler and others, 2010); however, mean ORP in shallow IWs generally decreased with increasing water-level depths and was inversely related to mean arsenic concentrations (fig. 6) because of more reducing conditions (smaller ORP values) at larger depths below the land surface. The shallow parts of the aquifer were subjected to substantial dewatering between 1940 and 1993. Larger dissolved arsenic concentrations in the shallow parts of the aquifer are associated with decreases in water levels and a subsequent 


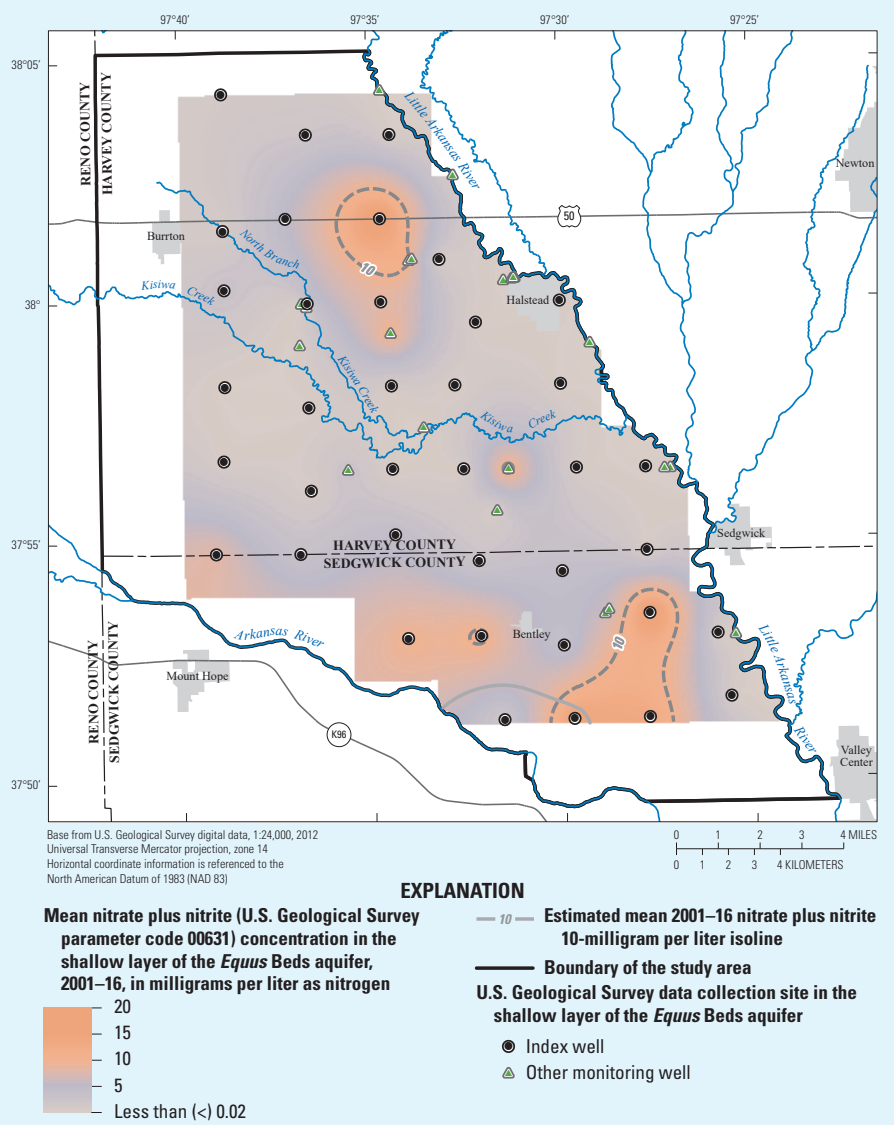

Figure 3. Mean nitrate plus nitrite concentrations in the shallow parts (depths below land surface equal to or less than 80 feet) of the Equus Beds aquifer, 2001-16. decrease in ORP, and thus more reducing conditions. Groundwater with an increased reducing potential (ORP values smaller than 250 millivolts) resulted in dissolution of arsenic in aquifer materials and an increase in dissolved arsenic concentrations (fig. 6).

\section{Atrazine}

Atrazine is an herbicide commonly used on corn and sorghum, crops commonly grown in the study area. The MCL for atrazine is $3.0 \mu \mathrm{g} / \mathrm{L}$ (U.S. Environmental Protection Agency, 2009), and atrazine concentrations exceeded the MCL in 39 percent of Little Arkansas River surface-water samples (table 1). Atrazine was detected in about 58 percent of shallow IWs and about 28 percent of deep IWs during 2001 through 2016, but the MCL for atrazine was not exceeded in groundwater IWs during the study (table 1).

\section{Groundwater Geochemistry}

Groundwater samples were assessed for a change in saturation index (SI), particularly near or across the equilibrium threshold of SI near zero. A mineral is of particular interest if its SI changes across equilibrium during the study period (for example, minerals for which the SI range includes negative and positive numbers). Minerals of most importance, as determined by predominant water types for the Equus Beds aquifer, include the carbonate minerals calcite and dolomite and iron hydroxides (Schmidt and others, 2007). SI values that were strongly and consistently negative or positive for groundwater samples indicate no change in overall equilibrium status with regard to those specific minerals during the study. Most minerals had SI values that were consistently negative. The minerals that had SI values that were consistently or typically positive included some iron oxide and hydroxide minerals and quartz group minerals.
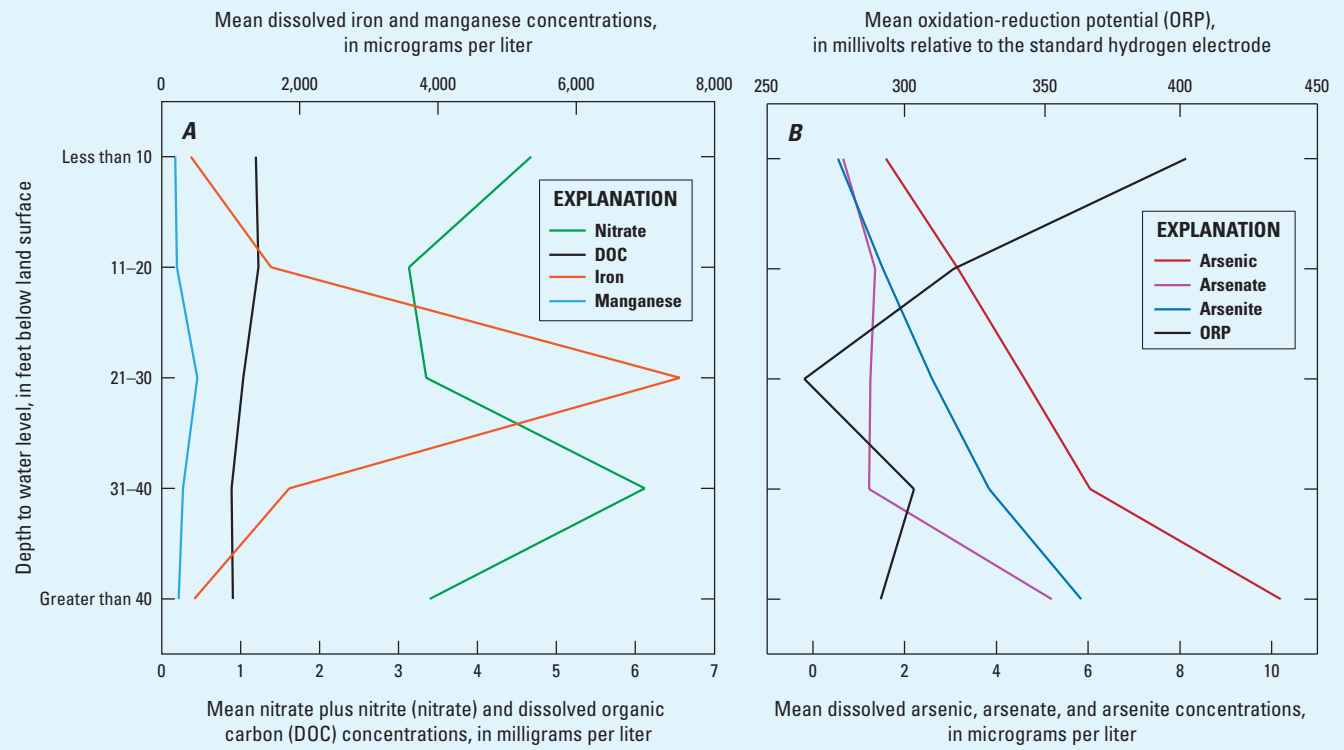

Figure 4. Relation between shallow (depths below land surface equal to or less than 80 feet) index well water-quality constituent concentrations in the Equus Beds aquifer, 2001-16. A, mean nitrate plus nitrite (nitrate; U.S. Geological Survey [USGS] parameter code [pcode] 00631), dissolved organic carbon (USGS pcode 00681), iron (USGS pcode 01046), and manganese (USGS pcode 01056) concentrations; and $B$, mean dissolved arsenic (USGS pcode 01000), arsenate (USGS pcode 62453), and arsenite (USGS pcode 62452) concentrations and oxidation-reduction potential (USGS pcode 63002) with depth to water level (USGS pcode 72019) ranges. 


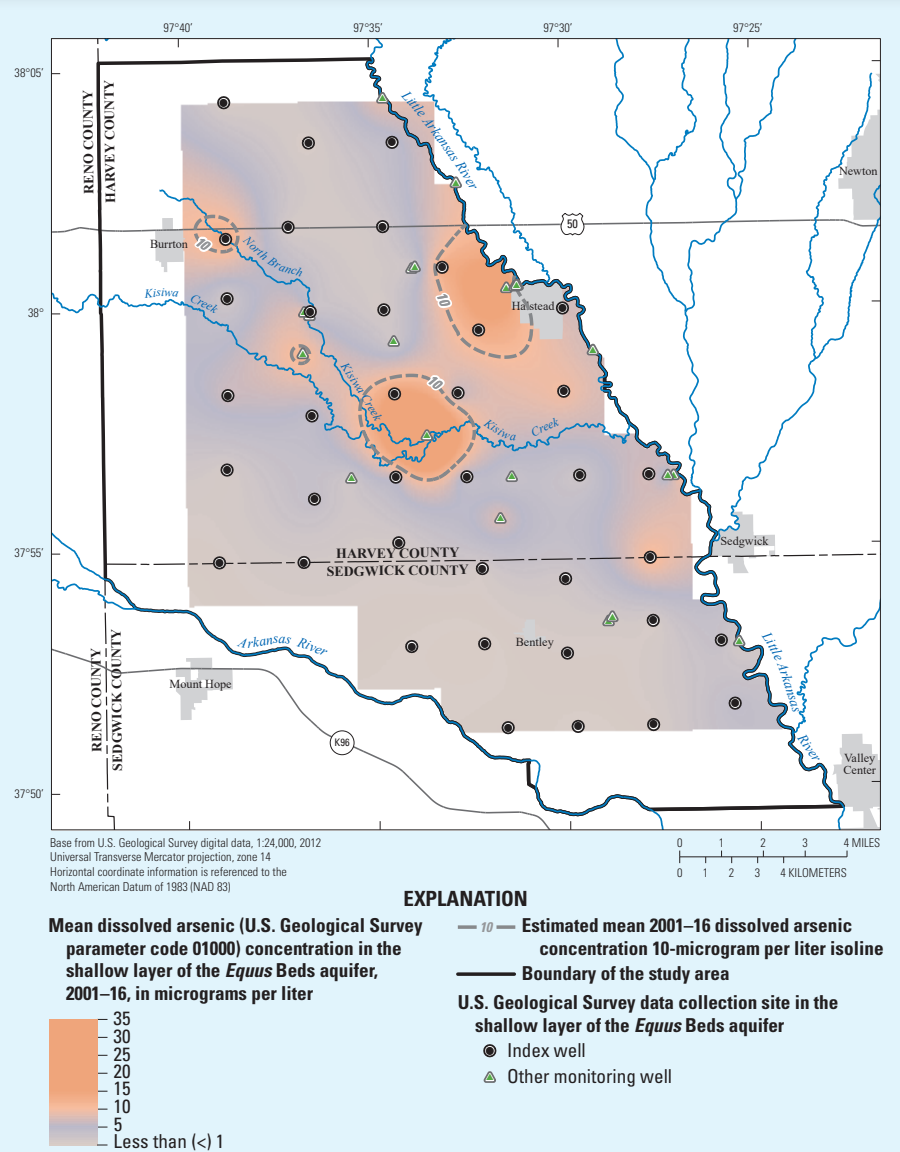

Figure 5. Mean dissolved arsenic concentrations in the shallow parts (depth below land surface equal to or less than 80 feet) of the Equus Beds aquifer, 2001-16.
Undersaturation (negative SI) of metal-bearing minerals can indicate potential for release of metals such as arsenic, which is harmful in drinking water.

Several carbonate (including calcite) and iron hydroxide (including iron [III] hydroxide and iron hydroxide) minerals in shallow and deep IWs varied across their equilibrium state during 2001 through 2016, indicating the potential for precipitation and possible reduction of injection well efficiency and bioplugging (table 1). Larger calcite SI values were detected more often in the deep parts of the aquifer but did not demonstrate a clear distributional pattern. Mean and median calcite SI values for shallow and deep IWs were negative (undersaturated) during the study period (table 1), indicating the potential for calcite dissolution if calcite is present for a substantial part of the study period. However, calcite SI values in this study also indicated saturation (table 1), and subsequent calcite precipitation may be detected within the study area; recharge activity has been determined to cause aquifer geochemistry to shift toward more oversaturated calcite SI values (Schmidt and others, 2007; Garinger and others, 2011; Stone and others, 2016), potentially resulting in formation of calcite mineral deposits that may reduce efficiency of injection wells. SI values with respect to iron hydroxide varied across equilibria during the study (table 1). Mean and median SI values with respect to iron hydroxide were undersaturated in shallow and deep IWs (table 1). However, some positive SI values indicated that, at times, groundwater in shallow and deep IWs was oversaturated with respect to iron hydroxide, there was potential for iron hydroxide precipitation, and the potential for biofouling by iron-related bacteria exists when fully oxygenated treated stream water is injected into the aquifer.
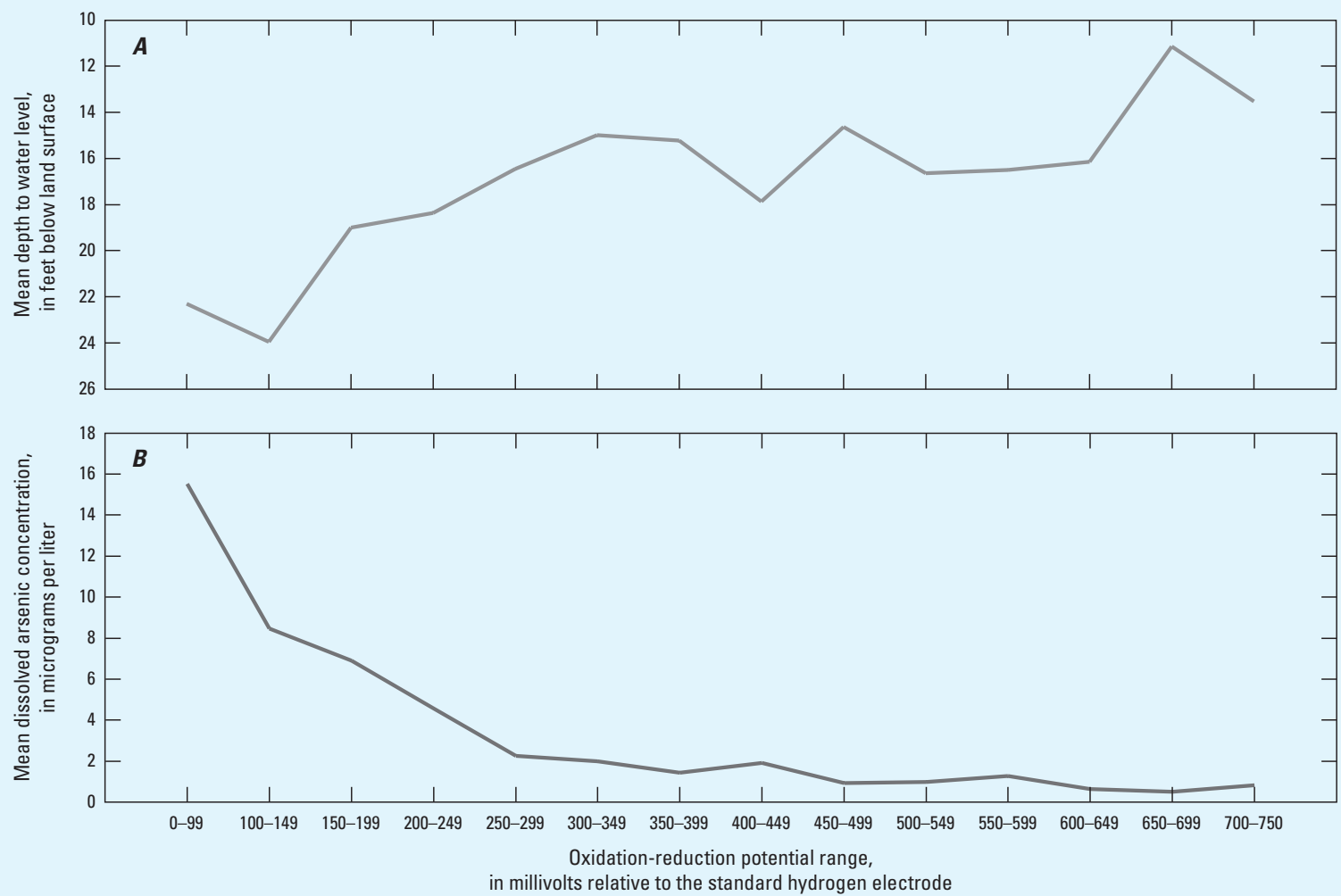

Figure 6. Relations between shallow (depths below land surface equal to or less than 80 feet) index well oxidation-reduction potential (U.S. Geological Survey [USGS] parameter code [pcode] 63002) ranges for mean dissolved arsenic (USGS pcode 01000) concentration in the Equus Beds aquifer, 2001-16. 


\section{References Cited}

Garinger, L.P., King, A.S., and Ziegler, A.C., 2011, Effects of experimental passive artificial recharge of treated surface water on water quality in the Equus Beds Aquifer, 2009-2010: U.S. Geological Survey Scientific Investigations Report 2011-5070, 106 p. [Also available at https://doi.org/10.3133/ sir20115070.]

Hansen, C.V., Whisnant, J.A., and Lanning-Rush, J.L., 2014, Status of groundwater levels and storage volume in the Equus Beds aquifer near Wichita, Kansas, 2012 to 2014: U.S. Geological Survey Scientific Investigations Report 2014-5185, 39 p. [Also available at https://doi.org/10.3133/ sir20145185.]

Juracek, K.E., and Hansen, C.V., 1995, Digital maps of the extent, base, top, and 1991 potentiometric surface of the High Plains aquifer in Kansas: U.S. Geological Survey Open-File Report 95-758, scales 1:500,000 and 1:1,000,000.

Klager, B.J., 2016, Status of groundwater levels and storage volume in the Equus Beds aquifer near Wichita, Kansas, January 2016: U.S. Geological Survey Scientific Investigations Report 2016-5165, 15 p. [Also available at https://doi.org/10.3133/sir20165165.]

Klager, B.J., Kelly, B.P., and Ziegler, A.C., 2014, Preliminary simulation of chloride transport in the Equus Beds aquifer and simulated effects of well pumping and artificial recharge on groundwater flow and chloride transport near the city of Wichita, Kansas, 1990 through 2008: U.S. Geological Survey Open-File Report 2014-1162, 76 p. [Also available at https:// doi.org/10.3133/ofr20141162.]

Leonard, R.B., and Kleinschmidt, M.K., 1976, Saline water in the Little Arkansas River basin area, south-central Kansas: Kansas Geological Survey Chemical Quality Series, no. 3, 24 p. [Also available at http://www.kgs.ku.edu/Publications/ Bulletins/CQS3/index.html.]

Schmidt, H.C.R., Ziegler, A.C., and Parkhurst, D.L., 2007, Geochemical effects of induced stream-water and artificial recharge on the Equus Beds aquifer, south-central Kansas, 1995-2004: U.S. Geological Survey Scientific Investigations Report 2007-5025, 58 p. [Also available at https://doi. org/10.3133/sir20075025.]

Stone, M.L., Garrett, J.D., Poulton, B.C., and Ziegler, A.C., 2016, Effects of aquifer storage and recovery activities on water quality in the Little Arkansas River and Equus Beds aquifer, south-central Kansas, 2011-14: U.S. Geological Survey Report 2016-5042, 88 p. [Also available at https://doi. org/10.3133/sir20165042.]

Stone, M.L., Klager, B.J., and Ziegler, A.C., 2019, Water-quality and geochemical variability in the Little Arkansas River and Equus Beds aquifer, south-central Kansas, 2001-16: U.S. Geological Survey Scientific Investigations Report 2019-5026, 79 p. [Also available at https://doi.org/10.3133/ sir20195026.]
Stramel, G.J., 1967, Progress report on the ground-water hydrology of the Equus-beds area, Kansas-1966: Lawrence, Kans., University of Kansas Publications, Kansas Geological Survey Bulletin 187, pt. 2, 27 p. [Also available at http:// www.kgs.ku.edu/Publications/Bulletins/187_2/.]

Stullken, L.E., Watts, K.R., and Lindgren, R.J., 1985, Geohydrology of the High Plains aquifer, western Kansas: U.S. Geological Survey Water-Resources Investigations Report 85-4198, 86 p. [Also available at https://pubs.er.usgs. gov/publication/wri854198.]

Tappa, D.J., Lanning-Rush, J.L., Klager, B.J., Hansen, C.V., and Ziegler, A.C., 2015, Water quality of the Little Arkansas River and Equus Beds aquifer before and concurrent with largescale artificial recharge, south-central Kansas, 1995-2012 (ver. 1.1): U.S. Geological Survey Scientific Investigations Report 2015-5023, 67 p. [Also available at https://doi. org/10.3133/sir20155023.]

U.S. Environmental Protection Agency, 2009, National primary drinking water regulations: U.S. Environmental Protection Agency, Report No. EPA 816-F-09-004, 7 p. [Also available at https://epa.gov/sites/production/files/2016-06/documents/ npwdr_complete_table.pdf.]

Whisnant, J.A., Hansen, C.V., and Eslick, P.J., 2015, Groundwater-level and storage-volume changes in the Equus Beds aquifer near Wichita, Kansas, predevelopment through January 2015: U.S. Geological Survey Scientific Investigations Report 2015-5121, 27 p. [Also available at https://doi.org/10.3133/sir20155121.]

Whittemore, D.O., 2007, Fate and identification of oil-brine contamination in different hydrogeologic settings: Applied Geochemistry, v. 22, no. 10, p. 2099-2114. [Also available at https://doi.org/10.1016/j.apgeochem.2007.04.002.]

Ziegler, A.C., Hansen, C.V., and Finn, D.A., 2010, Water quality in the Equus Beds aquifer and the Little Arkansas River before implementation of large-scale artificial recharge, southcentral Kansas, 1995-2005: U.S. Geological Survey Scientific Investigations Report 2010-5023, 143 p. [Also available at https://doi.org/10.3133/sir20105023.]

By Mandy L. Stone, Brian J. Klager, and Andrew C. Ziegler

For additional information concerning this publication, contact: Director, USGS Kansas Water Science Center

1217 Biltmore Dr.

Lawrence, KS 66049

(785) 842-9909

Or visit the Kansas Water Science Center website at: https://ks.water.usgs.gov 